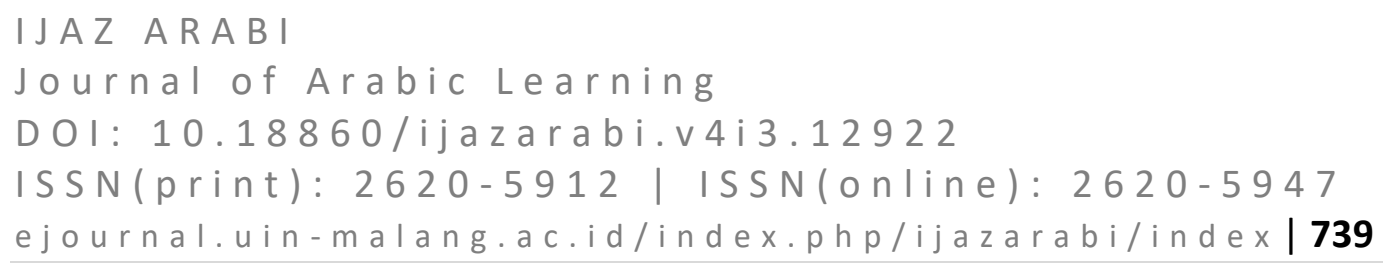

\title{
Conceptual Framework For Multilingual Bidayuh's Pupil In Teaching And Learning Arabic As Foreign Language
}

\author{
Muhammad Safreen Shafie ${ }^{1}$, Harun Baharudin² \\ Universiti Kebangsaan Malaysia ${ }^{1,2}$ \\ safreen.benyemin@gmail.com ${ }^{1}$, harunbaharudin@ukm.edu.my ${ }^{2}$
}

\begin{abstract}
This paper outlines the conceptual framework of the study that takes into account the elements of the environment during the learning and teaching sessions of Arabic as well as the role played by teachers as knowledge movers in giving the maximum possible Arabic experience to these Bidayuh's pupils, located in a rural area in Sarawak. In addition, the conceptual framework was created by combining two language theories, the bi/multilingual language theory by Cummins and the social theory by Vygotsky. These theories are relevant to be used and combined to suit the issues regarding teaching and learning the Arabic Language among Bidayuh's multilingual pupils. Arabic is their fourth or fifth language. Based on this conceptual framework, the combined two theories play a significant role in teaching multilingual pupils because it can be seen from the formation of language from the pupils' brain (common underlying proficiency). Teachers can strengthen the use of foreign languages by the Social Theory proposed. It is crucial to the teachers to know how to be competent to let the pupils use the language whereby the language is already stored in their brains. Based on that, the research came with 'The Shopping Cart' analogy. It describes the importance of teachers controlling the cart, which determines how competent they create the lesson (using social theory) while the things in the cart as the pupils and the cart itself as a lesson created. The analogy fills the 'paradigm gap' of previous studies in looking at how Arabic teachers in primary schools impart Arabic language education to pupils of different races and ethnicities.
\end{abstract}

Keywords: Arabic As Foreign Language; Teaching And Learning; Bidayuh Pupils; Multilingual Theory.

\section{INTRODUCTION}

Malaysia is one of the unique country and special country. The varieties of its races and ethnicity, effected the way they dress, food, religions, languages and many more in their lives. Despite all that, the education field also affected by this but in a positive way. From the educational perception, this varieties of races and ethnicity allows the Malaysian Ministry of Education to promote a variety of languages to be learnt at school starting from the primary school. Some of the languages offered in primary school are English, Chinese, Tamil, Bahasa Iban, Bahasa Kadazandusun and Arabic language. For example, from 2005, Chinese Communication Language (CCL) started to be taught in some of national 
primary school in order to grab the interest from other races to learn this language and by 2007, Chinese Communication Language (CCL) were replaced by the subject called Chinese Language (CL) which include in Malaysia Education Blueprint 2006-2010 (PIPP, 2006). By this plan, it allows all Malaysian pupils to learn other language from different races. For Arabic language, the implementation at primary school was started since 2005 until today and it was a mandatory for school who have a jQAF programme to teach this language to all Year 1 pupils (Anismazini Mohd Zin, 2014).

Judging by all languages provided to be taught at schools, Arabic however became the foreign language (Akta Pendidikan, 1996) and became more special as this language never been used or at least heard by the Malaysian in their daily life rather than other alternative languages such as Tamil and Chinese, where most of Malaysia at least familiar with this language somewhere. By that, this Arabic matter drag a bunch of scholars to study and doing the research in order to find detail about the Arabic implementation issues, challenges and solutions (Muhammad Safreen Shafie, Nik Mohd Rahimi, \& Harun Baharudin, 2019).

Arabic language subject spreading widely throughout schools across this country and recognized as important subject in our national educational system (Ashinida Aladdin \& Nurhafilah Musa. (2014); Mohd Fadzli \& Mohd Sukki, 2012). Some of the issues regarding Arabic language in Malaysia were discussed for example: Arabic vocabulary learning, some of the research discussed about the issue are Harun Baharudin (2014), Zunita Maskor \& Harun Baharudin (2016), Irma Martiny Md Yasim et.al (2017). Arabic learning technics from Hairun Najwah et.al. (2016) and Rosmaza Sukardi, Harun Baharudin \& Maimun Lubis,. (2016). The problem about teaching and learning Arabic discussed in Abdul Razif Zaini, Noor Shamsinar Zakaria, Ahmad Redzaudin Ghazali et.al (2017) and Zaini, Abdul et.al. (2017). The issues about motivational among students towards learning Arabic discussed in Shaffawati Abd Ghani et.al. (2016) and Abdul Halim et.al (2014).

Based on these researches, it can be concluded that all of these matter towards Arabic learning issues are leaning towards the teachers on how good they can manage to teach the lesson and change the behavior of their students by creating a conducive yet powerful learning environment. This is due the teacher as a main conductor who conducts and structured the lesson. Therefore the teachers need a skill and quality because only by that they can manage to deliver an effective lesson (Hyavärinen, K., Saaranen, T., \& Tossavainen, K.,(2015). The ministry of education also highlighted the importance of professional competencies among teachers (Panduan Pembangunan Guru Baharu, 2015) and research by Esmali Bari $\&$ Sufean (2014) on showing the importance of competencies among teachers.

As in Malaysia, the Arabic language already been taught throughout the country and learnt by varieties of pupils' races background (Muhammad Safreen Shafie, Nik Mohd Rahimi, \& Harun Baharudin, 2019) and not only eligible to Malay pupils only. This include those in Sarawak and Sabah from a multiple races which in this paper refereeing to Bidayuh pupils located in rural area in Sarawak. 


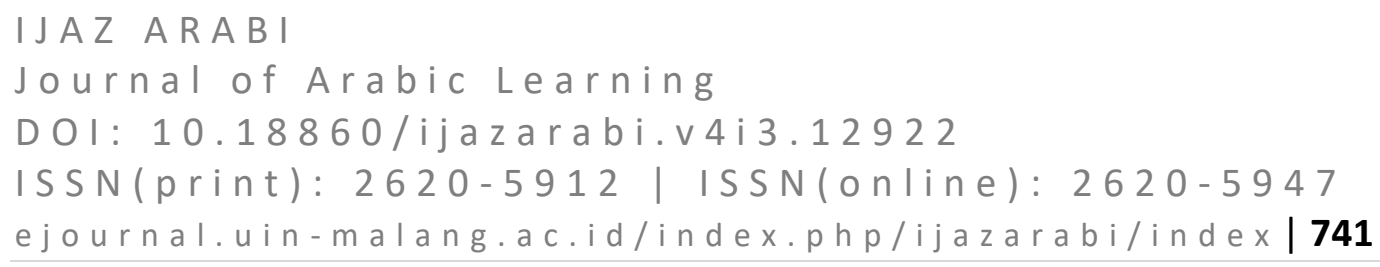

A research about Bidayuh people started as early from 1841 from Sir James Brooke. Bidayuh people also known as 'Land Dayak' (Chang, 2002) back in the colonial era, which the word 'Daya' itself comes from Bidayuh language meaning 'People' (Rensch, 2006). However today the people no longer using that term and commonly known as Bidayuh. The majority Bidayuh people lives in Kuching, Bau, Lundu, Serian and Padawan and this area known as 'Bidayuh Belt' (Dundon, 1989).

The Bidayuh people consisted from 29 ethnic and sub-ethnic all together and speaks different Bidayuh language and dialect even though they are from the same race (Dealwis \& David, 2007). They will use Bidayuh language according to their area (Dealwis \& David, 2007) for example Bidayuh people who live in Jagoi area in Bau District, will use Bidayuh-Jagoi language and those who live in Singgai area also in Bau District will use Bidayuh-Singgai language.

The majority of Bidayuh people can be considered as multilingual as they spoke 2 or more languages. Their first language is Bidayuh language or their mother tongue followed with Bahasa Malaysia, English, Bahasa Melayu Sarawak (Coluzzi, Riget \& Wang, 2013; Norazuna, 2010; Dealwis, 2008; Dealwis \& David, 2007). Therefore, the Arabic language as the Bidayuh pupils learn at school can be considered as foreign language.

By that fact, it is an opportunity for this paper to explore and discuss on how the multilingual Bidayuh's pupil learn Arabic language as their foreign language based on multilingual theory introduced by Cummins $(1980,1996)$ and combined with Vygotsky (1978) where the research look for the social relation between the teacher, and among the pupils themselves as they learning and how the teacher can manage the learning and teaching process as for the Bidayuh's pupils to learn Arabic.

\section{METHOD}

In this study, researchers intends to qualitatively gained and analysed the findings from 6 Arabic teachers, who teach 4 different primary schools in Bau, Sarawak, one of the state in Malaysia whereby the majority of Bidayuh population located here. The researchers not only interviewed the teachers but also 8 pupils age 8 to 12 years old from all 4 schools selected in order to find regarding this issues from their perspective as Bidayuh pupils. Observation also carried out while the teachers were teaching Arabic in the classroom during learning and teaching session. The pictures and the documents such as the teachers' teaching planning book and other related document also be analysed. The qualitative data from the study will undergo transcription and reported in themes and sub-themes.

\section{RESULTS AND DISCUSSION}

After comparing a varieties of bilingual and multilingual theories regarding the issue, the suitable theory for the Bidayuh pupils is the Common Underlying Proficiency (CUP) Model introduced by Cummins (1980, 1996). According to Common Underlying Proficiency (CUP) Model, every person and children who are able to talk more than 1 language have one operational system which controlling 
all of their languages inside their head. This operational system called 'Central Operating System'. The Central Operating System manage to produce any languages from someone's mind through cognitively process. It also can develop competencies from three different aspect which are literacy, abstract thinking, and problem solving (Baker, 1996). The CUP Model can be shown as an 'Iceberg analogy' in Figure 1.1 below,

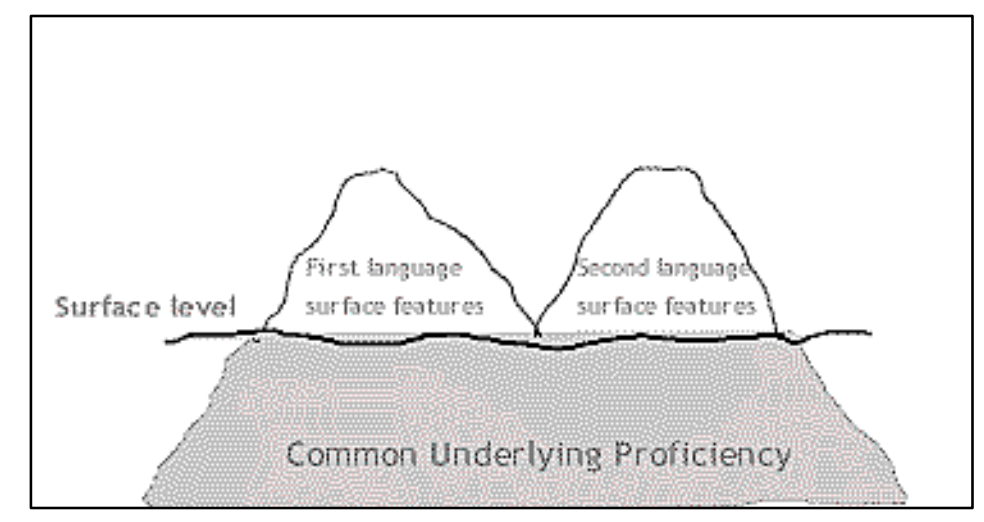

Figure 1: 'Iceberg’ Model Analogy in Common Underlying Proficiency (CUP)

The figure showed the Central Operating System which operating and controlling all the languages in someone's mind. The Figure 2 below showed a better understanding of the Common Underlying Proficiency (CUP) Model.

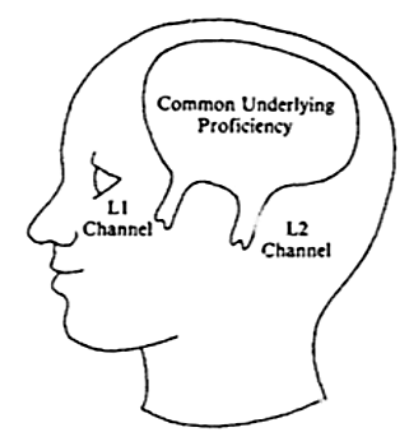

Figure 2: Common Underlying Proficiency (CUP), Cummins 1980,1996)

Meanwhile, As for Vygotsky theory (1978), regarding the language acquisition is by social relation where the interaction among others occurred (Lightbown \& Spada, 2013). This is relevant with the Vygotsky's principle which says 'the child as social' which mean the children learn more in a way of togetherness and socially interaction. The language acquisition can be obtained positively when the social relation or interaction existed and it would be better if the relation is in the same level for example the relation among pupils in the same level of their academic, their mother tongue language or their first and second language, (Brown, 2007). Vygotsky think that the children or the pupils can learn 


\section{IJAZ ARAB I}

Journal of Arabic Learning

DOI: $10.18860 / \mathrm{ijazarabi.v4i3.12922}$

ISSN(print): $2620-5912$ | ISSN(online): $2620-5947$

ejournal.uin-malang.ac.id/index.php/ijazarabi/index

better if they are all in the crowded situation or as in this context it can be referred to the learning in the classroom as a whole with the teacher. The pupils can learn quicker with the existed help by the teacher or their friends rather than learn alone by themselves.

In addition to social learning, the application of Vygotsky's theory is widely used to learn a foreign language by using the words of the language and associate them with objects. This over time will help build the ability of students to obtain additional information about the language and use a word and in addition to other words. In addition, the selection of this theory is important to prove the importance of teachers in providing a suitable learning environment for Arabic learning based on the concept of internalization proposed by Vygotsky that is the concept of transforming foreign language learning into the pupils. Besides, it is proven to be one of the effectives way for children to learn a language (Yusuf, $\mathrm{N}$ et.al, 2018). Based on the description of the theories and models that have been made, then this paper is positive to tend to the application of the conceptual framework of the study that adapts the Common Underlying Proficiency Model (CUP) from Cummins $(1980,1996)$ and also Sociocultural Theory from Vygotsky (1978). The modified conceptual framework of the study based on these two models of theories
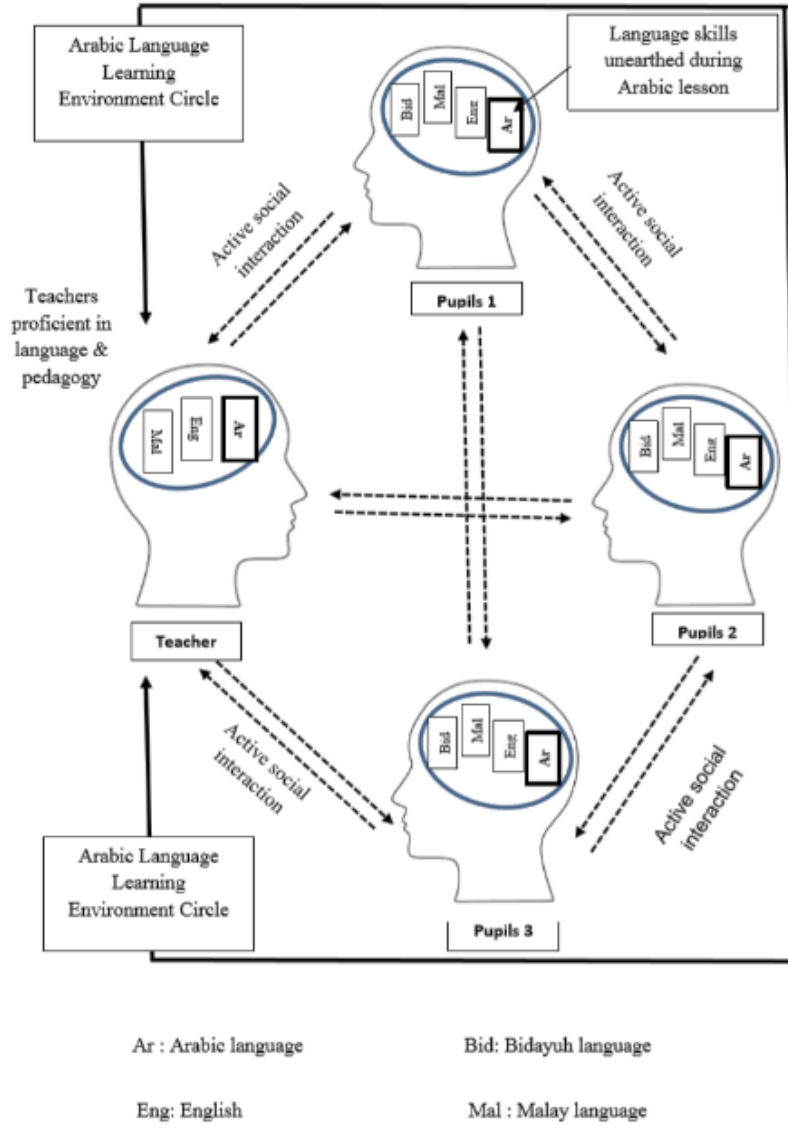

Figure 3: Conceptual Framework of the Study 


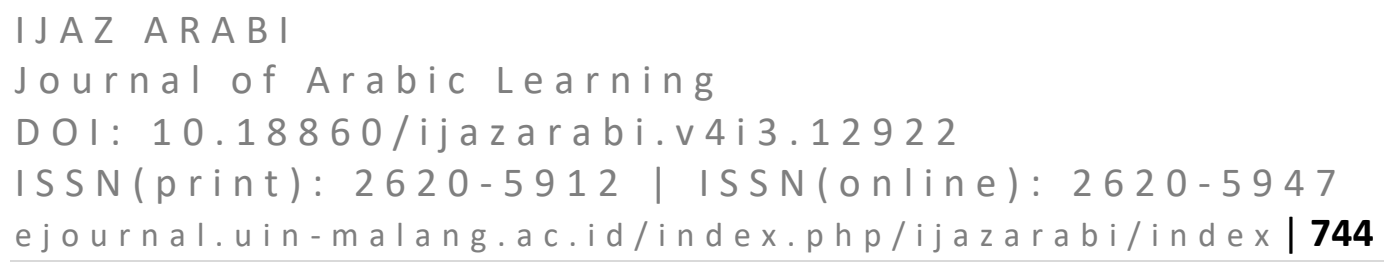

From the conceptual framework in Figure 3, Pupil 1,2, and 3 clearly shows a multilingual that is capable in the previous three languages, namely Bahasa Bidayuh (native language), Bahasa Melayu and English. The circle that surrounds each language in the pupils' brain is their cognitive space in line with the Common Underlying Proficiency (CUP) model which acts as a centralized operating system and pupils can access these language skills according to various languages desired for example in this study the language accessed is Arabic Language. This framework is in line with Chomsky's theory, which argues that humans are naturally or biologically capable of acquiring and mastering a language from birth. Addition from Brown (2007) states that if students have the same level and positive attitude towards the previous language such as Bidayuh and so on, then the process of learning a new language (Arabic) will be smooth and students will be able to master it. In the context of this study, all pupils are able and have almost the same language skills. Therefore the mastery of Arabic should be able to have a positive effect.

Social interactions are shown with arrows moving in all directions reciprocally. This indicates the need for active social interaction between all parties during the learning session to create an atmosphere of learning and adaptation of the language learned (Arabic). The 'Environment Circle' of the Arabic language learning environment that surrounds the whole individual in the classroom plays a very important role.

This environment circle makes the teacher as the leader which plays an important role in order to guide the lesson as it is one of the challenges faced while teaching Arabic language to Bidayuh's pupils (Muhammad Safreen Shafie, Nik Mohd Rahimi, \& Harun Baharudin, 2019). This is because the teacher who oversees all pupils' behavior and the entire Arabic language learning session. This includes the provision of activities that have a high impact and interesting, able to motivate students, create an atmosphere or 'biah 'Arabiyah' because this is an opportunity for pupils to get out of their 'Bidayuh' atmosphere. This can be realized with the interaction of Arabic completely without translation (use the language according to the level of students) and classroom conditions as well as activities that reflect the atmosphere of Arabic. With such an environment, teachers will be more focused on speaking Arabic and it is in line with the opinion of Cameron, L. (2001) who stated that teachers need to improve and think of ways to teach the language and the activities carried out. He added by stating that the character of the foreign language is contained in the extent to which the language is exposed to the pupil (skills and experience) (see also Turnbull, 2001). Therefore, teachers need to prepare students as much as possible to speak Arabic to create opportunities for pupils to learn and gain experience in Arabic. Citing the view of Cummins (2001): 'language must become an object of fascination and excitement' clearly describes what needs to be done during learning and teaching sessions in the classroom.

Describing about the needs for the teacher to be done can be monitored from the research findings by Rozaini Tukimin et.al. (2021) where there are eleven themes from the sources of teacher's innovation generated ideas which among of 


\section{IJAZ ARABI}

Journal of Arabic Learning

DOI: $10.18860 / \mathrm{ijazarabi.v4i3.12922}$

ISSN(print): $2620-5912$ | ISSN(online): $2620-5947$

ejournal.uin-malang.ac.id/index.php/ijazarabi/index

them are the use of popular songs, specific thinking practises, open source meaning the Internet and more. The role of teachers is more important through this framework not only due to the efficiency of conducting Arabic language learning sessions in the classroom but also the personality and professionalism of teachers are also questioned. In figure 1.3, Arabic teachers need good language knowledge and input in addition to being able to adjust their language skills according to the level of students. If the language is too high, students will not understand while if the level is too low, students will not learn something new or that challenges their 'IQ'. Cummins (1984) sternly warns any parent who does not encourage or speak with their child other than their mother tongue. However, in the context of the Bidayuh community, the majority of their parents are from the uneducated group, let alone speak Arabic. Therefore, this role is taken by Arabic teachers and with the cooperation of the school directly or indirectly (see also Lightbown \& Spada, 2013).

The selection of this conceptual theoretical framework is considered appropriate as there is no reason not to adapt to the Cummins model while Vygotsky himself suggested that the model be projected from bi-lingua ( 2 languages) to multilingua (3rd, 4th language) (Jonas Iversen, 2014) .

To gain a better understanding of this conceptual framework, the researcher describes the conceptual framework designed using the analogy of 'The Shopping Cart' as illustrated in figure 4 below:

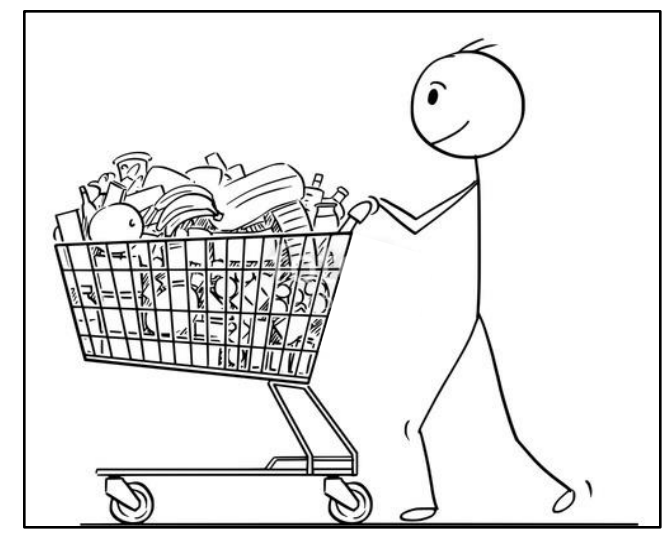

Figure 4: Analogy of 'The Shopping Cart'

As described in the analogy shown in figure 4, 'The Shopping Cart', pupils are described as items purchased that have different shapes, uses, sizes and so on. All these items, although not the same physically and in different condition, these items are put in the same cart which is analogous to the environment of Arabic learning environment or as the 'Environment Circle' (based on the figure 3 before). The person who is pushing the trolley is the teacher who is competent on the task and the act of pushing the trolley is symbolic to the task of the teacher who plans and in turn moves the language learning activities that are interesting, fun and effective. 
Based on that, it is clearly describe how important the teacher in order to deliver the Arabic lesson to a bunch of different type of pupils not only different in their socially life, attitude, and level but also as multilingual pupils. The teacher need to be able and ready to create the lesson which can be impacted to trigger the Arabic language in the pupils' mind according to the conceptual framework discussed before. By the realization of the teacher's readiness including knowledge and skills to conquer the lesson to these multilingual pupils, it is hope that this conceptual framework is beneficial to the teachers especially the novice to prepare themselves so that the Arabic language can be taught throughout the nation and across races.

\section{CONCLUSION}

The Overall, this paper discusses in theory by combining two language acquisition theories which suit the issues regarding of Arabic language towards Bidayuh pupils. This paper aim to fill the 'paradigm gap' of previous studies in looking at how Arabic teachers in primary schools, especially those in rural areas of Sarawak in imparting knowledge of Arabic language education to students of different nationalities.

This paper outlines the conceptual framework of the study that takes into account the elements of the environment during the learning and teaching sessions of Arabic in the classroom as well as the role played by teachers as knowledge movers in giving the maximum possible Arabic experience to these Bidayuh pupils. By knowing the part of the teachers from the framework, it is hope that the teacher can trigger the Arabic language placed somewhere in their pupils' mind and make sure that the knowledge not only can be transferred but also in a more efficient way of learning and teaching especially those in a minority ethnics as Bidayuh.

\section{ACKNOWLEDGMENTS}

This work was supported by the Ministry of Higher Education Malaysia (FRGS/1/2019/SSI09/UKM/03/2). The authors wish to thank the people who help this study and the projects which financially support this study. Thank you so much for reviewers' valuable suggestions to help us to improve our manuscript quality.

\section{REFERENCES}

Ab. Halim Ismail. (2006). pengajaran bahasa arab melalui kaedah komunikatif. Dlm. Hassan Basri Awang Mat Dahan, Zawawi Ismail \& Muhammad Azhar Zailani. (pnyt.). Pendidikan Islam dan bahasa Arab: Perspektif Pengajian Tinggi, hlm. 137-162. Kuala Lumpur: Penerbit Universiti Malaya

Abdul Razif Zaini, Noor Shamsinar Zakaria, Ahmad Redzaudin Ghazali, Mohd Rofian Ismail, Hasmadi Hamdan, Ahmad Zabidi Abdul Razak, Rushdan Azizan, Naqibah Mansor. (2017), Kompetensi Guru Bahasa 
IJAZ ARAB I

Journal of Arabic Learning

DOI: $10.18860 / \mathrm{ijazarabi.v4i3.12922}$

ISSN(print): $2620-5912$ | ISSN(online): $2620-5947$

ejournal.uin-malang.ac.id/index.php/ijazarabi/index/747

Arab Dalam Pengajaran Bahasa Arab Di Sekolah Rendah Kementerian Pendidikan Malaysia. Laporan Geran Penyelidikan Inovasi KUIS 2016. Abdul Razif Zaini, Muhammad Redzaudin, Rufian Ismail, Noorshamsinar Zakaria, Hasmadi Hamdan \& Mohamad Rushdan. (2017). Permasalahan Dalam Pengajaran Bahasa Arab Di Malaysia, http://conference.kuis.edu.my/pasak2017/images/prosiding/pendidika n/31-DR.ABDUL-RAZIF.pdf

Anismazini Mohd Zin (2014) Permainan bahasa dalam pembelajaran bahasa Arab di sebuah sekolah rendah di Klang / Anismazini binti Mohd Zin. Master thesis, University of Malaya.

Ashinida Aladdin \& Nurhafilah Musa. (2014). Arabic Language Courses for Students at the Faculty of Law UKM - Importance and Challenges. Procedia - Social and Behavioral Sciences. 118. 51-55. 10.1016/j.sbspro.2014.02.007.

Baker, Mark C., (1996). Of Parameters and Polysynthesis. The Polysynthesis Parameter. Oxford University Press. 3-38. Reprinted, with permission from Oxford University Press, (C) 1996 by Oxford University Press.

Brown, D.H. (2007). First Language Acquisition. Principles of Language Learning and Teaching,. 5th Ed. Pearson ESL. Pgs. 24-51.

Cameron, L. (2001). Teaching languages to young learners. Cambridge: Cambridge University Press.

Chang, P.F. (2002), History of Bidayuh in Kuching Division, Sarawak, Kuching Sarawak Press Sdn.Bhd, Kuching.

Coluzzi, Paolo \& Riget, Patricia \& Xiaomei, Wang. (2013). Language Vitality among the Bidayuh of Sarawak (East Malaysia). Oceanic Linguistics. 52. 375-395. 10.1353/ol.2013.0019.

Cummins, J. (1980). Psychological assessment of immigrant children: Logic or intuition? Journal of Multilingual and Multicultural Development, 1, 97-111.

Cummins, J. (1984). Bilingualism and Special Education: Issues in Assessment and Pedagogy. Clevedon: Multilingual Matters.

Cummins, J. (2001). Negotiating identities: Education for empowerment in a diverse society (2nd ed.). Los Angeles: California Association for Bilingual Education.

Dealwis C., M. K. David, (2007), Shy Speakers: Hearing Their Voices, Migracijske i etničke teme 23, 1-2: 51-64

Dealwis, Caesar (2008) Language choice among Dayak Bidayuh undergraduates / Caesar Delwis@Dealwis. PhD thesis, Universiti Malaya.

Dundon, J. Stephen (1989). "Bidayuh Language and Dialect", Sarawak Museum Journal, 30, pp. 408-409.

Esmali, B., \& Sufean, H. (2014). Kompetensi Profesional Guru Sekolah Rendah di Sabah: Satu Tinjauan. Jurnal Pendidikan, 34. 
IJAZ ARAB I

Journal of Arabic Learning

DOI: $10.18860 / \mathrm{ijazarabi.v4i3.12922}$

ISSN(print): $2620-5912$ | ISSN(online): $2620-5947$

ejournal.uin-malang.ac.id/index.php/ijazarabi/index/ 748

Hairun Najuwah Jamali, Awatif Abd Rahman, Ku Fatahiyah Ku Azizan, \& Siti Nurhajariah Md Isa, (2016), Membina Kemahiran Bertutur Dalam Bahasa Arab Melalui Teknik Main Peranan, e-Journal of Arabic Studies \& Islamic Civilization e-ISSN: 2289-6759 Volume 3-2016, Page 89.

Harun Baharudin, (2014) Strategi Pembelajaran Kosa Kata Bahasa Arab Pelajar Sekolah Menengah Agama di Malaysia, PhD thesis, University of Malaya.

Hyvärinen, K., Saaranen, T., \& Tossavainen, K. (2015). A Teacher' s Professional Competence and Occupational Well-being - a Survey for Finnish Health Care Sector Teachers A Teacher' s Professional Competence and Occupational Well-being - a Survey for Finnish, ECER 2015, Education and Transition. European Educational Research Association. $1-3$

Irma Martiny Md Yasim, Maimun Aqsha Lubis, Zaid Arafat Mohd Noor, Aisyah Sjahrony (2017), ASEAN Comparative Education Research Journal on Islam and Civilization (ACER-J) Volume 1(1) January 2017, 14-24.

Iversen, Jonas. (2014). Bilingualism in Norwegian Schools. 10.13140/RG.2.2.28509.20965.

Lightbown, P. M., \& Spada, N. (2013). How languages are learned (4th ed.)

Mohd Fadzli Ismail \& Mohd Sukki Othman. (2012). Faktor-Faktor Yang Mempengaruhi Pencapaian Pelajar Dalam Pengajaran \& Pembelajaran Bahasa Arab:Satu Tinjauan Di SMAP Kajang. Bangi. Universiti Kebangsaan Malaysia.

Norazuna Norahim, (2010) Language choice of Bidayuh graduates in KuchingSamarahan division. $\mathrm{PhD}$ thesis, Universiti Malaya.

Pelan Induk Pembangunan Pendidikan (PIPP 2006 - 2010), Kementerian Pendidikan Malaysia, (2006),

Rensch, C.R, Rensh, C.M., J\& Ridu, R.S. (2012), The Bidayuh Language: Yesterday, Today and Tomorrow (Revised and Expanded) Retrieved from

01.sil.org/silepubs/Pubs/9284748010/ebook_33_Bidayuh_6-21-

12_rev.pdf

Shaffawati Ab Ghani, Fatin \& Harun Baharudin, (2016). Pendekatan 'Mobile Learning' Dalam Meningkatkan Motivasi Pelajar.

Muhammad Safreen Shafie, Nik Mohd Rahimi, \& Harun Baharudin, (2019). Insight Arabic Teacher: The Challenges and Solutions to Arabic for Bidayuh's Pupils. Creative Education. 10. 2658-2670. 10.4236/ce.2019.1012193.

Rosmaza Sukardi, \& Harun Baharudin,\& Maimun Lubis,. (2016). Konsep Gamification Sebagai Kaedah Meningkatkan Motivasi Dalam Pembelajaran Bahasa Arab Di Malaysia. Kolokium Pendidikan Bahasa Arab 2016 (KOBAR '16)

Rozaini Tukimin, \& Nik Mohd, Rahimi \& Harun Baharudin, (2021). Source of Ideas of Teacher-Generated Innovation in Teaching Arabic Language 
in Primary Schools. International Journal of Academic Research in Progressive Education and Development. 9. 2226-6348. 10.6007/IJARPED/v9-i2/8893.

Turnbull, A. P., \& Turnbull, H. R. (2001). Families, professionals, and exceptionality: Collaborating for empowerment (4th ed.). Upper Saddle River, NJ: Merrill/Prentice Hall.

Nabihah Yusof, \& Harun Baharudin, \& Maimun Lubis, \& Muhammad Saiful Anuar Yusoff, (2018). Persepsi Pelajar Terhadap Penggunaan Kaedah Bimbingan Rakan Sebaya (BRS) Untuk Pembelajaran Kosa Kata Arab Learners' Perception of Peer Tutoring (Pt) Method For Arabic Vocabulary Learning. 7. 2289-6589.

Vygotsky, L. S. (1978). Mind in Society: the Development of Higher Psychological Processes. Cambridge, MA: Harvard University Press.

Zunita Maskor \& Harun Baharudin, (2016). Receptive Vocabulary Knowledge or Productive Vocabulary Knowledge in Writing Skill, Which One Important?. International Journal of Academic research in Business and Social Sciences, Vol 6 (11), 261-271 (ERA Indexed) 